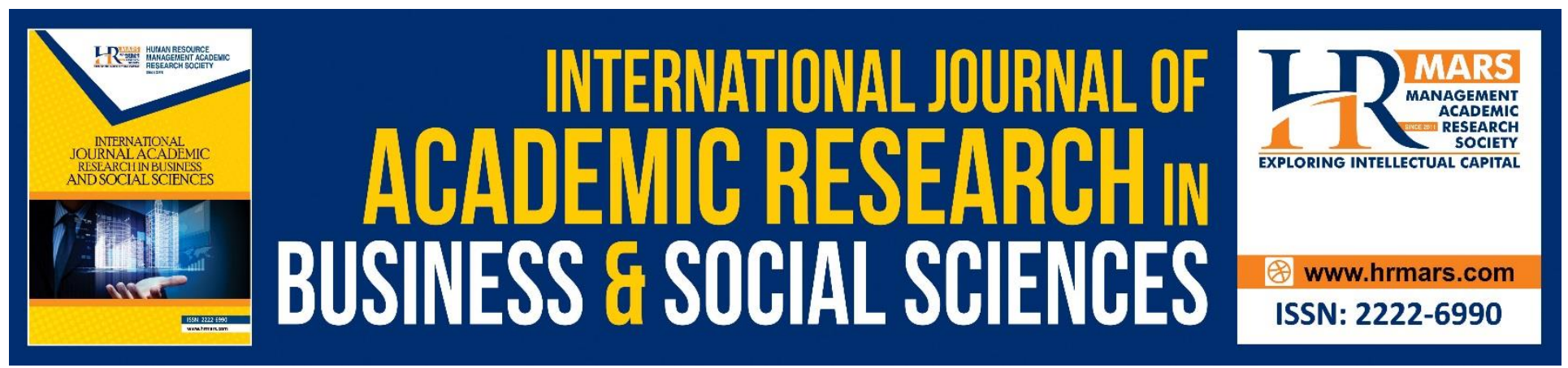

\title{
Entrepreneurial Intention from the Islamic Perspective: A Holistic Approach
}

Norliana Abd Majid, Fakhrul Anwar Zainol, Wan Norhayate Wan Daud, Norfadzilah Rashid, Asyraf Afthanorhan

To Link this Article: http://dx.doi.org/10.6007/IJARBSS/v8-i12/5077

DOI: $10.6007 /$ IJARBSS/v8-i12/5077

Received: 23 Oct 2018, Revised: 30 Nov 2018, Accepted: 16 Dec 2018

Published Online: 30 Dec 2018

In-Text Citation: (Majid, Zainol, Daud, Rashid, \& Afthanorhan, 2018)

To Cite this Article: Majid, N. A., Zainol, F. A., Daud, W. N. W., Rashid, N., \& Afthanorhan, A. (2018). Entrepreneurial Intention from the Islamic Perspective: A Holistic Approach. International Journal of Academic Research in Business and Social Sciences, 8(12), 820-833.

Copyright: (C) 2018 The Author(s)

Published by Human Resource Management Academic Research Society (www.hrmars.com)

This article is published under the Creative Commons Attribution (CC BY 4.0) license. Anyone may reproduce, distribute, translate and create derivative works of this article (for both commercial and non-commercial purposes), subject to full attribution to the original publication and authors. The full terms of this license may be seen

at: http://creativecommons.org/licences/by/4.0/legalcode

Vol. 8, No. 12, 2018, Pg. 820 - 833

http://hrmars.com/index.php/pages/detail/IJARBSS

JOURNAL HOMEPAGE

Full Terms \& Conditions of access and use can be found at http://hrmars.com/index.php/pages/detail/publication-ethics 


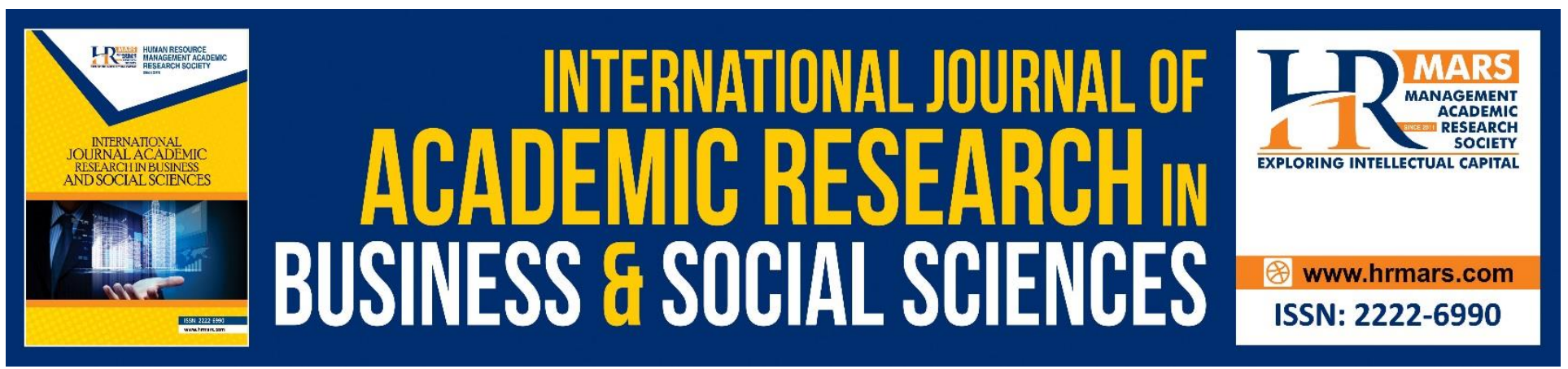

\title{
Entrepreneurial Intention from the Islamic Perspective: A Holistic Approach
}

\author{
${ }^{1}$ Norliana Abd Majid, ${ }^{2}$ Fakhrul Anwar Zainol, ${ }^{3}$ Wan Norhayate Wan \\ Daud, ${ }^{4}$ Norfadzilah Rashid, ${ }^{5}$ Asyraf Afthanorhan \\ 1,2,3,4,5 Faculty of Economics and Management Sciences, Universiti Sultan Zainal Abidin, \\ 21300 Kuala Nerus, Terengganu, Malaysia \\ Corresponding Author : fakhrulanwar@unisza.edu.my
}

\begin{abstract}
An intention is an individual's internal desire to predict behaviour. As an all-encompassing religion, Islam is a way of life that places priority on the intention of its believers that leads to their actions. In the field of entrepreneurship, previous researches have proven that entrepreneurial intention has a crucial role in predicting entrepreneurial behaviour. This topic of entrepreneurial intention has been attracting considerable attention and thus generating an abundance of literature. However, discussions on entrepreneurial intention from the Islamic perspective are still limited and lack the interest from researchers. Thus, the primary purpose of this conceptual paper is to explore entrepreneurial intention from the Islamic perspective. The discussion begins with an elaboration of the importance of religion in entrepreneurship. Then, it deliberates on the concept of intention in Islam and provides a review of the antecedents of entrepreneurial intention in Islamic practices. The literature review leads the researchers to imply a conceptual framework for the relationship between entrepreneurial knowledge, entrepreneurial motivation and entrepreneurial intention through religious belief as a moderator.
\end{abstract}

Keywords: Entrepreneurial Intention; Islamic Perspective; Entrepreneurial Knowledge; Entrepreneurial Motivation; Religious Belief

\section{Introduction}

Entrepreneurs and entrepreneurship are the drivers of the domestic economy. Hence, the need for entrepreneurs' development and advancement model is indispensable (M. N. Hakimin, Fakhrul Anwar, \& M. Dahlan, 2015). In shaping entrepreneurs, religion and education are the significant elements of the socio-cultural business environment, which influences entrepreneurial intention (Ahmad Isa \& Fakhrul Anwar, 2016). Max Weber, among the pioneer researchers on entrepreneurship, has linked it with religion. Weber presents the entrepreneurship theory through the sociological or social approach, by incorporating religious elements as the basis for an 
INTERNATIONAL JOURNAL OF ACADEMIC RESEARCH IN BUSINESS AND SOCIAL SCIENCES Vol. 8, No. 12, Dec, 2018, E-ISSN: 2222-6990 @ 2018 HRMARS

entrepreneur's success. His study was based on the success of the Protestant religion in the economic field at the time. According to Weber, Kalberg, and Kebede (1930), universal religious values such as honesty are essential in moving entrepreneurial activities.

Faith in religion creates a diligent and responsible attitude in working and contributes to the accumulation of productive assets. Virtuous endeavours are the most critical aspects in entrepreneurship. Moral values in an individual will encourage the person to change for the better (Ahmad Isa \& Mustapha Shitu, 2015). Naturally, most religious tradition, in one way or another, deals with the relationship between entrepreneurship and religion (Weber et al., 1930). This correlation is attributed to the widely accepted notion that religion positively affects human's daily lives (Wibowo, 2017). Religious values and entrepreneurship are therefore intertwined, as religion instils ethical values in individuals which will encourage them to positively respond to the environment, meet the community's needs and constructively strive for success.

In the Islamic perspective, entrepreneurship is parallel to the encouragement of Muslim to strive for the most exceptional sustenance by getting the best of living. Seeking profit or wealth is not an obstacle in Islam, as stated in Surah al-Jum'ah, verse 10, which means; "Then when the prayer is over, then disperse in the land, and seek what you desire from Allah's bounty, and remember Allah much (in all things) that you may prosper in this world." (Quran 62:10, Telaga Biru Sdn Bhd). This verse explains that Allah does not prevent anyone from searching for as much as God's favour, which they like, includes from business and entrepreneurship. However, a Muslim should not ignore His commands.

Also, Islam encourages its people to be self-employed to find legitimate provisions without asking others. The Prophet, peace be upon him (PBUH) said that; "It is better for anyone of you to take a rope and cut the wood (from the forest) and carry it over his back and sell it (as a means of earning a living) rather than to ask a person for something, and that person may give him or not." (Narrated by Bukhari) (Khan, 2009). This hadith explains that Muslim is better to pursue an opportunity to provide for oneself, rather than to rely on someone to provide it (K.Davis, 2013). Thus, entrepreneurship is indeed promoted in Islam to ensure the well-being of human life.

Moreover, entrepreneurship is even regarded as a form of prayer or devotion (ibadah) through business or enterprise activities with specific skills aimed to obtain Allah's gift, for the worldly profit as well as spiritual benefits for the hereafter (Zain \& Mubarak, 2015). Entrepreneurship involves activity, process and business creation which implies engagement of entrepreneurs as a decision maker and coordinator of resources (Ramadani, Dana, Ratten, \& Tahiri, 2015). The purpose of entrepreneurship is not only to generate the economy and the needs of the ummah but also to develop a quality of human capital with the formation of more Muslim's personality traits and attitudes (Zain \& Mubarak, 2015). Fundamentally, in Islam, participation in entrepreneurship is claimed as one of the societal obligations or known as fardhu kifayah in Arabic. Muslims are much encouraged to contribute directly or indirectly towards a thriving economy, essentially meeting the demands of the ummah and entrepreneurial involvement in an example.

Historically, Islamic entrepreneurship has long started since the time of Prophet Muhammad (PBUH) and his companions. Prophet Muhammad (PBUH) was a successful entrepreneur who has succeeded in building a holistic entrepreneurial culture through proper techniques, actions, 
INTERNATIONAL JOURNAL OF ACADEMIC RESEARCH IN BUSINESS AND SOCIAL SCIENCES Vol. 8, No. 12, Dec, 2018, E-ISSN: 2222-6990 C 2018 HRMARS

ways of working, decisions and insights and have produced prominent entrepreneurial figures amongst the companions at the time. The recognition of his character as a successful entrepreneur is an example for people to continuously strive to improve themselves (Muslim Kelana, 2011).

Recently, studies in the field of entrepreneurship from the Islamic perspective have gained the attention of many researchers, but only a few from those studies delved explicitly on entrepreneurial intention. Most of them relate religion to economic activity, especially entrepreneurship; either directly or indirectly. According to Nadratun Nafisah, Muhammad Nasri, and Abdullah (2017), religion can be assessed as a moderator variable in strengthening the relationship between motivation and the firm's success in financial or non-financial terms. The influence of religion is also found to have a positive relationship with the motivation and success of the firm in many previous studies. In a study conducted in Malaysia on 206 Muslim entrepreneurs found a positive correlation between their achievement of property jihad and human jihad (Yazilmiwati, 2015).

Miles K. Davis in his study of entrepreneurship from an Islamic perspective proposes an Islamic entrepreneurial model, which highlighted the Prophet Muhammad (PBUH) as the role model of a successful entrepreneur. He also suggested for the exemplary entrepreneurs to act as stewards, Quran and hadith as the source of wisdom for entrepreneurs, and the submission to God will serve as a motivation for entrepreneurship. Finally, he put the primary quality of an entrepreneur into concern for the community (K.Davis, 2013). These discussions on entrepreneurship in Islam indicates that the religion encourages its believers to take part in entrepreneurship. Consequently, the objective of this paper is to explore entrepreneurial intention from the Islamic perspective.

\section{Problem Statement}

Many studies on entrepreneurship have emphasised the importance of entrepreneurial intention in shaping and producing entrepreneurs (Krueger, Reilly, \& Carsrud, 2000). This emphasis is further supported in a study by Ahmad Isa and Fakhrul Anwar (2016), implying that entrepreneurial intention plays an influencing role in forming entrepreneurs. Among the earliest pioneer researchers on entrepreneurial intention are Ajzen's Theory of Planned Behavior (TPB) and Shapero's Model of Entrepreneurial Event (SEE). According to TPB, Perceived Behavioral Control, Attitude and Subjective Norm are the main factors that influence the intention towards entrepreneurial behaviour. Meanwhile, SEE specified three essential antecedents to predict entrepreneurial behaviour; namely Perceived Desirability, Perceived Feasibility and Propensity to Act. According to Krueger, Reilly, and Carsrud (2000), both of these two models are successful in predicting entrepreneurial intention towards entrepreneurial behaviour. However, recent studies see more rapid developments with the use of TPB to predict entrepreneurial intention as most studies adopt the TPB model. According to Israr and Norashidah (2015), in research on the trend of entrepreneurial intention; out of the 69 articles reviewed, 44 are studies on entrepreneurial intention; and among the 44 research, 22 used the TPB model in their studies.

Despite the numerous researches on entrepreneurial intention, studies on the Islamic perspective are still limited. In line with the perfection of Islam as a way of life, this paper will discuss the concept of entrepreneurial intention from the Islamic point of view, since Islamic teachings cover all aspects of human life, including on matters of economic and muamalah. This paper begins with 
an introduction on the role of religion towards entrepreneurship, followed by an Islamic view on the importance of entrepreneurship. The paper then further deliberates the concept of intention in Islam along with deliberations on entrepreneurial intention from other studies. Additionally, it discusses the role of Islamic belief in shaping entrepreneurs from the aspects of quantity and quality. Towards the end, the paper presents its proposed conceptual framework and a summary of the conclusion with several recommendations for further research.

\section{Literature Review}

\section{Entrepreneurial Intention and Religion}

There is limited literature on the impact of religion on entrepreneurial intention. In a study conducted in Indonesia by Wibowo (2017), the researcher compared between two groups of students; a religious and non-religious group and implied that religion affects entrepreneurial intention by influencing the student's perceptions. Wibowo (2017) measured the individual level of religious beliefs during daily activities through the adaptation of the Theory of Planned Behavior (TPB). The finding shows that the religious group has a higher persistence towards entrepreneurial intention as compared to the non-religious one. The outcome of the study proves that religion strengthens the entrepreneurial intention by influencing an individual's self-assessment of his or her abilities and forming a productive attitude towards entrepreneurial behaviour. The study also suggested that the religious students had a stronger influences of personal attitude and perceived behavioural control towards entrepreneurial activity.

In another study, Riaz, Farrukh, Shams-Ur-Rehman, and Ishaque (2016) found that people who increasingly adhere to a religion, have a higher likelihood of entrepreneurship involvement. This study included 290 students from the final year of business education in the private sector universities in Lahore, Pakistan. In this study, religion affects the entrepreneurial intention by shaping individuals' personality through daily activities. Similar research on the impact of religion on entrepreneurial intention was also conducted in Nigeria. The empirical study of 380 students at the Northwest University, Kano showed that religion has a highly significant impact on entrepreneurial intention (Ahmad Isa \& Mustapha Shitu, 2015).

Researchers of Indonesia also did a quantitative study on entrepreneurial intention from the Islamic perspective from September to November of 2015 in several cities of the country. The Indonesian authors also remarked on the limitation of prior studies on Islamic entrepreneurship in the area of entrepreneurial intention. The researchers conducted the study on 250 Muslim entrepreneurs, and highlighted two crucial findings; firstly, intention becomes the most critical factor in determining actions in entrepreneurial activities, aside from all other activities in life. The second finding was the impact of the entrepreneurial activities on entrepreneurial characters are based on five main attributes; intelligence and competence (fathonah), trustworthiness (amanah), truthful and high integrity (siddiq), conveying or communicative (tabligh), and consistency of courage (istiqomah). The study suggested that researches on entrepreneurial intention from the Islamic outlook are not only useful for business startups, but can also be a guide for Muslim entrepreneurs in conducting their business according to Islamic laws (Ratten, Alamanda, Ramadani, Hashani, \& Anggadwita, 2017). Hence, studies on entrepreneurial intention and its 
association to religion need to be more publicised and increased, because of the significant impact of religion on individuals.

\section{Overview of Intention in Islam}

The role of intention is much emphasised in Islam that every practice is to be initially performed with a good intention. A hadith by Prophet Muhammad (PBUH) recorded, "Actions are judged by motives (niyyah), so each man will have what he intended"; narrated by Bukhari and Muslim. This hadith is known as one of the greatest hadith in Islam. What the Prophet said assists Muslim to evaluate and judge internal acts (action of hearts) in daily life (Ahmed Badi, 2002). The hadith proves that Islam places a vital concern on the intention of every Muslim's actions. For a clear view and understanding of niyyah (intention), this study will simplify the discussion of intention in Islam into the following subjects:

\section{Purposes and role of intention}

Based on the Quran, Hadith and Qias, the intention is compulsory for all practices to differentiate between acts of worship and custom procedures. The intention is a requirement in determining one's actions and distinguishing between different acts of worship (Ahmed Badi, 2002). According to Imam Nawawi in Sharh Arba'een, niyyah or intention has two significances in Islam; firstly, the affirmation of intention is a prerequisite before an ibadah or worship, such as in the daily prayer. Secondly, the affirmation of niyyah signifies one's willingness. The meaning of the hadith above by the Prophet (PBUH) refers to the second definition that is, willingness.

\section{Intention and sincerity (Ikhlas)}

The above hadith also emphasises ikhlas or sincerity, which means to be truthful and honest to Allah in doing ibadah (worship). Ikhlas is one of the conditions of accepting a good deed. To achieve ikhlas, a Muslim has to avoid shirk (associating others with Allah), which will cause insincerity (Ahmed Badi, 2002). Although ikhlas lies in one's heart, it is also demonstrated via one's behaviour.

\section{Intention \& Reward}

Good intentions will be rewarded even if they are not implemented, on the contrary, bad intentions are not subject to sin unless implemented (Mujiburrahman, 2011). One's intention could even determine whether the person is rewarded by his/her actions or the deeds are only done in vain, hence will not be rewarded (Jasmi \& Kamarul Azmi, 2016). Muslims must make sure that the actions are for the sake of Allah for it to be accepted and rewarded by Him (Ahmed Badi, 2002).

Ultimately, we can get a better understanding of the explanation by Imam Nawawi, who said that the intention in term of language means intentionally and heart determination. Meanwhile, in terminology, intention means unpretentious in the heart accompanies with deeds (Ahmed Badi, 2002). Thus, if a person is only unpretentious in the heart but did not yield any actions, it is then only 
INTERNATIONAL JOURNAL OF ACADEMIC RESEARCH IN BUSINESS AND SOCIAL SCIENCES

Vol. 8, No. 12, Dec, 2018, E-ISSN: 2222-6990 C 2018 HRMARS

considered as a determination or ambition and not the intention (Mujiburrahman, 2011). Islam sees the intention from a different point of view and even describes in it in a much-detailed account. According to syarak, the intention is the purpose of heart towards all deeds and actions, solely to seek the pleasure of Allah. Intention or niyyah which aims only to obtain Allah's approval will lead to a positive behaviour (Salmah S, Kalsom AW, Asmaddy H, \& Nordin AR, 2015). Therefore, Islam emphasises that a good intention not only determines a positive behaviour but also consequently guides people to practice good deeds.

\section{Entrepreneurial intention from the Islamic perspective Entrepreneurial knowledge}

According to Al-Ghazali, the intention is a will that rises from the soul due to the desire and tendency of something that is suitable for the purposes or what to achieve, whether in the world or hereafter. Hence, intention (niyyah) emerges when knowing about what is desired. When the intention arises, then it moves into actions, through strength (qudrah). Therefore, Al-Ghazali concludes that intention (niyyah) is in the middle of knowledge ('ilm) and action ('amal) (Mujiburrahman, 2011).

This opinion coincides with previous studies, which found that entrepreneurial knowledge has a positive correlation with entrepreneurial intention and serves as an essential factor (Ibrahim \& Mas'ud, 2016). Entrepreneurial knowledge is also found to increase the positive perception towards entrepreneurial intention (Liñán, Rodríguez-Cohard, \& Rueda-Cantuche, 2011). Meanwhile, the research on entrepreneurial intention among the science and technology students in India suggests that entrepreneurial knowledge publishes a positive attitude towards entrepreneurial behaviour (Roy, Akhtar, \& Das, 2017). There is even a study that proves students who are inculcated with entrepreneurial knowledge would gain entrepreneurial skills and are more likely to have the entrepreneurial intention (M. N. Hakimin et al., 2015). As a result, this paper suggests integrating entrepreneurial knowledge as a predictor of entrepreneurial intention from the Islamic perspective.

\section{Entrepreneurial Motivation}

Although there is an effort to integrate the relationship between entrepreneurial intention and entrepreneurial motivation, studies about the influence of entrepreneurial motivation on entrepreneurial intention still need to be explored (Solesvik, 2013). Some researchers have divided entrepreneurial motivation into specific antecedents, namely; risk tolerance and self-efficacy (perceived feasibility and perceived desirability) (Achchuthan, S.\& Nimalathasan, 2012). Entrepreneurial motivation indicates a significant relationship with entrepreneurial intention, which proves that entrepreneurial motivation is vital in translating entrepreneurial intention into actions (Malebana, 2014).

Al-Ghazali, a Muslim scholar, explained the intention where he stated that the power to complete an action would rise based on motivation (F.Shaker, 2013). In the Islamic perspective, motivation is influenced by spirituality, which consists of piety (taqwa), trust in Allah (tawakkal), contentment (qana'ah), and patience (sabr). According to Isa Mohammed, Zulkarnain, and OsmanGani (2011), spirituality can motivate a person to do better work for the sake of seeking Allah's pleasure. The more spiritual a person is, the more motivated the person is to work by obtaining Allah's blessing and moreover, in Islam, entrepreneurship is also considered as an act of worship to 
INTERNATIONAL JOURNAL OF ACADEMIC RESEARCH IN BUSINESS AND SOCIAL SCIENCES

Vol. 8, No. 12, Dec, 2018, E-ISSN: 2222-6990 C 2018 HRMARS

Allah. In this conceptual paper, entrepreneurial motivation is considered as the antecedent which will influence the entrepreneurial intention towards entrepreneurial behaviour.

\section{Religious belief (Islamic faith)}

This paper views the term 'religion' from the standpoint of Islam. As mentioned earlier in this paper, religion plays a vital role in forming an entrepreneurial intention. Therefore, this paper suggests that the Islamic faith among Muslims should moderate the impact of entrepreneurial motivation and entrepreneurial knowledge towards entrepreneurial intention. Islamic faith will enable a person to see the cognisance (ma'rifat), which means the inner sense of that individual; and perceive the guidance (hidaya) from Allah in any actions (F.Shaker, 2013). Hence, this belief will strengthen the dependence on Allah (tawakkal), thus addressing any challenges of either to start a new business or subsequent phases.

\section{Entrepreneurial intention/niyyah (willingness and ikhlas)}

Sincerity or ikhlas means doing something for the sake of Allah. Imam Sayuti stated that intention lies in the heart rather than on the tongue. Hence, the intention must be laid out at the beginning of the action. The four things that contradict acts of sincerity (ikhlas) are; committing sins (ma'siat), associating other deities with Allah (shirk), performing worship to show off (riy $a^{\prime}$ ) and hypocrisy (nifaq) (Ahmed Badi, 2002). Sincerity is born from an understanding of religion. The conception of the faith will enable individuals to understand the real goals they want to achieve by engaging in entrepreneurship. As stated by Imam Al-Ghazali, a willingness will incline the heart towards what the person thinks is in line with the future goal (F.Shaker, 2013). Furthermore, Imam Nawawi explained in achieving ikhlas, the person must seek for knowledge and must verify his or her intention before acting (Ahmed Badi, 2002). Therefore, this paper emphasises that sincerity in the entrepreneurial intention ensure an upright practice in entrepreneurial behaviour.

\section{Entrepreneurial behaviour with good deeds}

According to Ratten et al., (2017), entrepreneurial activities initially begin with the individual's intention in running a business, before achieving Al-Falah (success). A respectable intention in an entrepreneur will foster principled entrepreneurial characteristics and qualities in business practice; such as intelligence and competence (fathonah), trustworthiness (amanah), truthfulness and high integrity (siddiq), communicative (tabligh), and consistency of courage (istiqomah). Imam Al-Ghazali stated that a noble action is like a good fruit that grows from a good root (F.Shaker, 2013). This conceptual paper asserts that religious belief leads to the noble intention of obtaining Allah's pleasure and thereby directs entrepreneurs towards excellent qualities.

\section{The Conceptual Framework}

The conceptual framework for entrepreneurial intention in the Islamic perspective is shown in Figure 1 below. The framework underlines the antecedents that can predict entrepreneurial intention and the consequences of the niyyah. 
INTERNATIONAL JOURNAL OF ACADEMIC RESEARCH IN BUSINESS AND SOCIAL SCIENCES Vol. 8, No. 12, Dec, 2018, E-ISSN: 2222-6990 @ 2018 HRMARS

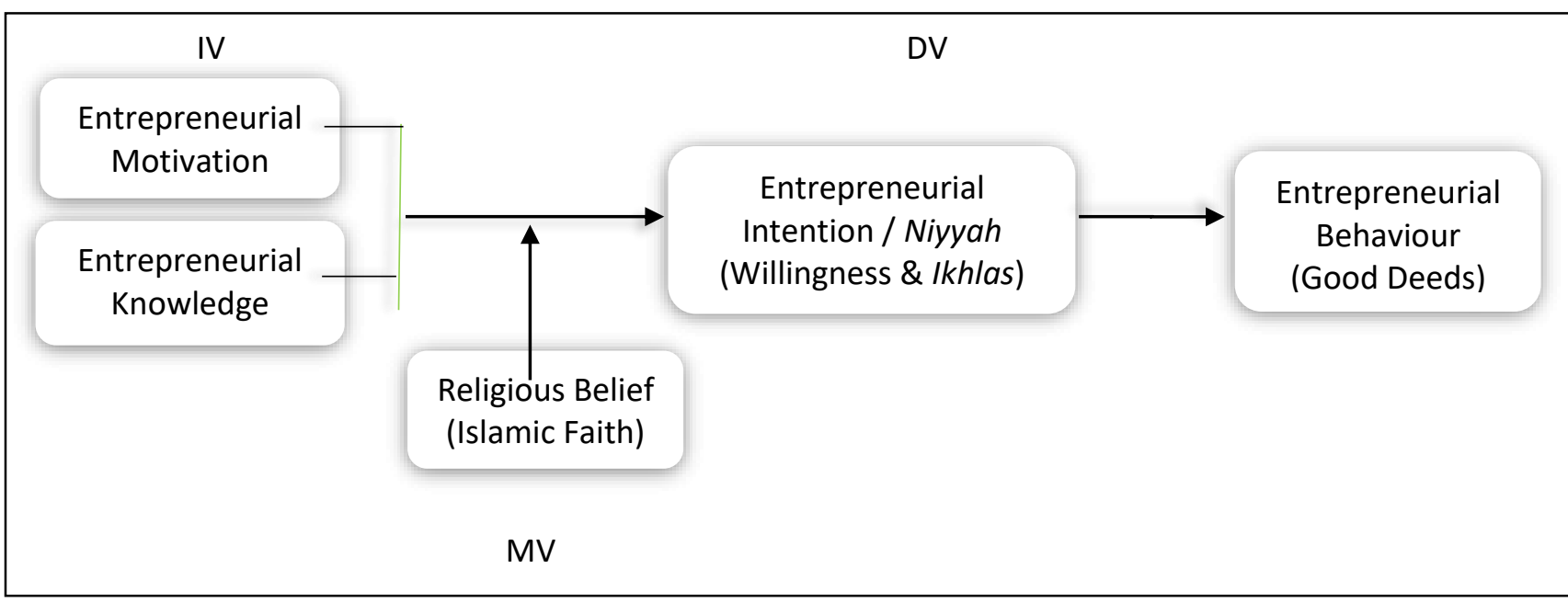

\section{Comparison between the Islamic and Western Perspective of Entrepreneurial Intention (EI)}

The literature on entrepreneurial intention (EI) is mostly found from the western perspective. These studies proved that factors such as attitude and perceived behaviour control influence the El, and the social norm is a weak determinant of the El (Nadia \& Nawaz, 2017). Another study identified other factors such as the need for achievement, entrepreneurial education, and economic situation as significant variables in determining the El. Interestingly, the study also found that family background and desire for independence fail to predict entrepreneurial intention (Joseph, 2017). Additionally, a study by Ibrahim and Mas'ud (2016) stated that entrepreneurial skills and environmental factors posit a positive influence on El. The researches above exhibit a compelling consideration of the El, by focusing on the influencing factors; namely motivational, perceptual and environmental factors.

This paper attempts to contribute to the corpus of knowledge by deliberating the Islamic views on El and the factors affecting it. For that reason, the researchers of this paper examined the opinions of Islamic scholars. A well-known Islamic scholar, Imam Nawawi emphasised that knowledge is a prominent element in intensifying the intention of any action (Ahmed Badi, 2002). This opinion is supported by another distinguished Muslim scholar, Imam Al-Ghazali, who stated that intention comes in between knowledge and action (F.Shaker, 2013). Thus, they implied that knowledge is the primary requirement to generate intention (Mujiburrahman, 2011). To illustrate this notion, Zaidatol, Bagheri, and Sani (2013), provides the example that a person who is involved in entrepreneurial activities must have knowledge about entrepreneurship, such as the types of entrepreneurship, the procedures to open a new venture, and how to manage the business to trigger entrepreneurial intention. Besides that, in Islamic perspective, motivation is also a significant predictor in raising the intention towards an action (F.Shaker, 2013). Intrinsic and extrinsic motivation will arouse desire, and thus triggering intentions towards an action. According to Al-Ghazali, the intention is the will (iradah) contributed by the desire and the tendency towards achieving a purpose. In other words, intentions appear when one is motivated by the desire of achieving a goal (Mujiburrahman, 2011). Hence, entrepreneurial knowledge and entrepreneurial motivation are identified as two important determinants to lead towards the entrepreneurial intention in Islamic perspective. 
INTERNATIONAL JOURNAL OF ACADEMIC RESEARCH IN BUSINESS AND SOCIAL SCIENCES Vol. 8, No. 12, Dec, 2018, E-ISSN: 2222-6990 @ 2018 HRMARS

Aside from Muslim researchers, western researchers also recognise the influence of entrepreneurial knowledge and entrepreneurial motivation towards entrepreneurial intention. According to Barba-Sánchez \& Atienza-Sahuquillo (2017), entrepreneurial motivation has a positive effect on entrepreneurial intention by influencing the need for independence in a person. This opinion is supported by Malebana (2014), who stated that both intrinsic and extrinsic rewards and the need for independence could motivate a person to engage in entrepreneurship. As one of the influencers of $\mathrm{El}$, researchers have also conducted studies on the effects of entrepreneurial knowledge towards El. On this note, Yusuf, Abdul, Poespowidjojo, and Muhammed (2017) found a positive and significant relationship between entrepreneurial knowledge and entrepreneurial intention among university graduates. The findings by Province \& Farani (2016) also illustrated the influence of entrepreneurial knowledge and entrepreneurial skills towards El. All these findings agree on the impact of the two determinants; knowledge and motivation towards the intention to become an entrepreneur.

Based on Reasoned Action Approach (2010), which is also illustrated by the Theory of Planned Behaviour (TPB); the antecedents of entrepreneurial intention appear from one's belief which will form the individual's perception. According to this approach, the antecedent of attitude towards behaviour is derived from behavioural beliefs. Meanwhile, social norms and perceived behavioural control are triggered by normative and control belief, respectively. All these beliefs will configure the individual's perception, which influences the intention towards the behaviour (Nisson \& Earl, 2015); (Kakouris, 2016). The researchers of this paper assert and support that these beliefs are related to religion, and religion can control such beliefs, as implied by Kroessin (2008), and Koenig \& Al Shohaib (2014). Therefore, this research proposes appointing religious belief as a moderator which can dominate individual beliefs, by enriching the dependence on Allah (tawakkal).

Islamic El differs from the western El because of the accentuation on the sincerity (ikhlas) in the intention. Hence, the willingness to venture into entrepreneurship accompanied with sincerity will publish ethical and responsible conducts in entrepreneurial behaviour. According to Ramadani, Dana, Ratten, and Tahiri (2015), the ultimate goal of gaining Allah's approval hinders Muslims from unethical entrepreneurial and business practices such as fraud, oppression, and usury. Gaining Allah's pleasure is the priority in the practice of Islamic El; the Hereafter benefits are deemed as the principal goal which precedes materialistic objectives. Even so, Islam does not disregard the aspects of gaining profit. Islamic El posits higher importance on the public interest rather than personal interest. This position distinguishes the superiority and prominence of the Islamic El over the western El. Ultimately, Islamic El is a holistic approach to producing entrepreneurs who are successful businesspersons and yet constructive in the desires for gains towards the Hereafter, which is an added value in entrepreneurs, as they will always conform to ethical ways in business dealings. The table below is a summary of the differences between the Islamic and western El as discussed above. 
INTERNATIONAL JOURNAL OF ACADEMIC RESEARCH IN BUSINESS AND SOCIAL SCIENCES

Vol. 8, No. 12, Dec, 2018, E-ISSN: 2222-6990 C 2018 HRMARS

\begin{tabular}{ll}
\hline \multicolumn{1}{c}{$\begin{array}{c}\text { Entrepreneurial Intention (EI) from } \\
\text { the Islamic Perspective }\end{array}$} & \multicolumn{1}{c}{$\begin{array}{c}\text { Entrepreneurial Intention (EI) from } \\
\text { the Western Perspective }\end{array}$} \\
\hline $\begin{array}{l}\text { A holistic approach by emphasising and relating } \\
\text { entrepreneurial intention and behaviour to } \\
\text { spiritual aspects. }\end{array}$ & $\begin{array}{l}\text { Only focuses on certain factors such as } \\
\text { motivational, perceptual and environmental } \\
\text { factors. }\end{array}$ \\
\hline $\begin{array}{l}\text { Emphasize on sincerity (ikhlas) in setting niyyah } \\
\text { (entrepreneurial intention). }\end{array}$ & $\begin{array}{l}\text { There is no emphasis on sincerity in the western } \\
\text { approach of El. }\end{array}$ \\
\hline $\begin{array}{l}\text { Pure entrepreneurial intentions aimed at } \\
\text { obtaining Allah's approval will gain rewards } \\
\text { (pahala) from the Creator }\end{array}$ & Not related to any rewards (pahala or dosa). \\
\hline $\begin{array}{l}\text { Entrepreneurial knowledge is an essential } \\
\text { determinant of entrepreneurial intention, as } \\
\text { suggested by Imam Al-Ghazali } \\
\text { ((Mujiburrahman, 2011). }\end{array}$ & $\begin{array}{l}\text { The studies on entrepreneurial knowledge in the } \\
\text { western standpoint did not have much emphasis } \\
\text { like the Islamic El. }\end{array}$ \\
$\begin{array}{l}\text { Religious belief is placed as the variable to } \\
\text { increase the impact of entrepreneurial } \\
\text { knowledge and motivation towards } \\
\text { entrepreneurial intention by fertilising tawakkal } \\
\text { (dependence with Allah), even in any decisions } \\
\text { made in the entrepreneurship. }\end{array}$ & $\begin{array}{l}\text { The role of religious belief is not explained } \\
\text { although there is some previous researches on }\end{array}$ \\
\hline $\begin{array}{l}\text { El from the Islamic perspective contributes to } \\
\text { the respectable conducts in entrepreneurial } \\
\text { behaviour. }\end{array}$ & $\begin{array}{l}\text { The western El only predicts the entrepreneurial } \\
\text { intention and ignores the consequences on the } \\
\text { entrepreneurial behaviour. }\end{array}$ \\
$\begin{array}{l}\text { Islamic El is related to human life in the world } \\
\text { and hereafter. }\end{array}$ & $\begin{array}{l}\text { Western El predicts entrepreneurial intention } \\
\text { towards entrepreneurial behaviour solely for } \\
\text { worldly purposes. }\end{array}$ \\
\hline
\end{tabular}

\section{Table 1: Comparison between Islamic El and Western EI}

\section{Conclusion}

Islam places a high emphasis on entrepreneurial intention. Individual involvements in entrepreneurial activities are also considered as worship to fulfil the demands of fardhu kifayah; which is the societal responsibility in Islam to meet the needs of the community and contribute towards the people's daily essentials (Salwa, Shahbudin, \& Jusoff, 2013). An entrepreneurial intention from the Islamic perspective gives a more precise and adequate understanding and prediction of entrepreneurial behaviour. The Islamic approach is a holistic one, especially in the effort of instilling entrepreneurship among the young generation. This paper concludes from the Islamic perspective in five statements; firstly, the entrepreneurial intention appears before entrepreneurial behaviour. Secondly, the entrepreneurial intention is not only essential to predict the entrepreneurial behaviour for new business ventures, but Islam stresses on the whole actions involved in handling business, including ethical manner. Furthermore, Islam advocates its believers to obtain Allah's pleasure and blessing in entrepreneurial involvement as pleasing the Creator is regarded as the most significant intention. Fourthly, religious belief (Islamic belief) enables a person to defy the negative perceptions 
INTERNATIONAL JOURNAL OF ACADEMIC RESEARCH IN BUSINESS AND SOCIAL SCIENCES Vol. 8, No. 12, Dec, 2018, E-ISSN: 2222-6990 @ 2018 HRMARS

and fear of failure in entrepreneurial behaviour, and fertilise a sense of tawakkal (dependence on Allah) after carrying out an effort. The conclusion is entrepreneurial knowledge and motivation influence entrepreneurial intention, which also signifies the importance of a proper objective and adequate learning before committing to a business. Ultimately, the findings from this conceptual paper will contribute to both academicians and practitioners, and further empirical research on entrepreneurial intention is highly recommended.

\section{References}

Achchuthan, S.\& Nimalathasan. (2012). Entrepreneurial motivation and self employment intention : a case study on management undergraduates of university of Jaffna. Serious in Management Business( Economics and Entrepreneurship). University of Kellaniya, SriLanka, 7790.

Ahmad Isa, A., \& Fakhrul Anwar, Z. (2016). The Impact of Socio-cultural Business Environment on Entrepreneurial Intention: A Conceptual Approach. International Journal of Academic Research in Business and Social Sciences, 6(2). https://doi.org/10.6007/IJARBSS/v6-i2/2013

Ahmad Isa, A., \& Mustapha Shitu, S. (2015). Impact of Religion on Entrepreneurial Intention of University Students in Kano State, Nigeria. International Conference on Empowering Islamic Civilization in the 21st Century E-ISBN:, (September), 363-375.

Ahmed Badi, J. (2002). Sharh Arba'een an Nawawî COMMENTARY OF FORTY HADITHS. In Fortyhadith.Com (p. 220). Retrieved from http://fortyhadith.iiu.edu.my/

Barba-Sánchez, V., \& Atienza-Sahuquillo, C. (2017). Entrepreneurial intention among engineering students: The role of entrepreneurship education. European Research on Management and Business Economics, 1-9. https://doi.org/10.1016/j.iedeen.2017.04.001

F.Shaker, A. (2013). Al-Ghazālī on Intention, Sincerity and and Truthfulness (Kitab al-niyya wa'likhlas wa'l sidq). United Kingdom.

Ibrahim, N. A., \& Mas'ud, A. (2016). Moderating role of entrepreneurial orientation on the relationship between entrepreneurial skills, environmental factors and entrepreneurial intention: A PLS approach. Management Science Letters, 6, 225-236.

https://doi.org/10.5267/j.msl.2016.1.005

Isa Mohammed, A., Zulkarnain, K., \& Osman-Gani, A. (2011). Spirituality in Entrepreneurship from Islamic Perspectives: A Conceptual Analysis on the Effects on Entrepreneurial Motivation and Social Responsibility. In 10th International Conference of the Academy of HRD (Asia Chapter) (p. December 3-6, 2011). Kuala Lumpur, Malaysia. Retrieved from http://heinonlinebackup.com/hol-cgibin/get_pdf.cgi?handle=hein.journals/condp33\&section=32

Israr, A., \& Norashidah Hashim. (2015). Research on Entrepreneurial Intention: an Academic Literature Review and Classification. Journal of Commerce, Economics, and Social Sciences, 9(1), 43-62.

Jasmi, \& Kamarul Azmi. (2016). Niat dan Ikhlas. In Pendidikan Islam (Edisi Pert, pp. 88-90). Universiti Teknologi Malaysia.

Joseph, I. (2017). Factors Influencing International Student Entrepreneurial Intention in Malaysia, 424-428. https://doi.org/10.4236/ajibm.2017.74030 
INTERNATIONAL JOURNAL OF ACADEMIC RESEARCH IN BUSINESS AND SOCIAL SCIENCES Vol. 8, No. 12, Dec, 2018, E-ISSN: 2222-6990 @ 2018 HRMARS

K.Davis, M. (2013). Entrepreneurship from an Islamic Perspective. Journal of Business Ethics, 20(1), 63-69. https://doi.org/10.1007/s10551-014-2223-7

Kakouris, A. (2016). Exploring entrepreneurial conceptions, beliefs and intentions of Greek graduates. International Journal of Entrepreneurial Behavior and Research, 22(1), 109-132. https://doi.org/10.1108/IJEBR-07-2014-0137

Khan, T. M. M. (2009). Sahih Bukhari.

Koenig, H. G., \& Al Shohaib, S. (2014). Health and well-being in Islamic societies: Background, research, and applications. Health and Well-Being in Islamic Societies: Background, Research, and Applications, 9783319058, 1-361. https://doi.org/10.1007/978-3-319-05873-3

Kroessin, M. R. (2008). Religions and Development Research Programme Concepts of Development in 'Islam': A Review of Contemporary Literature and Practice. Interpreting. United Kingdom. Retrieved from http://www.rad.bham.ac.uk

Krueger, N. F., Reilly, M. D., \& Carsrud, A. L. (2000). Competing models of entrepreneurial intentions. Journal of Business Venturing, 15(5-6), 411-432. https://doi.org/10.1016/S08839026(98)00033-0

Liñán, F., Rodríguez-Cohard, J. C., \& Rueda-Cantuche, J. M. (2011). Factors affecting entrepreneurial intention levels: A role for education. International Entrepreneurship and Management Journal, 7(2), 195-218. https://doi.org/10.1007/s11365-010-0154-z

M. N. Hakimin, Y., Fakhrul Anwar, Z., \& M. Dahlan, I. (2015). Entrepreneurship education in Malaysia's public institutions of higher learning-A review of the current practices. International Education Studies, 8(1), 17-28. https://doi.org/10.5539/ies.v8n1p17

Malebana, M. J. (2014). Entrepreneurial Intentions and Entrepreneurial Motivation of South African Rural University Students. Journal of Economics and Behavioral Studies, 6(9), 1-19. https://doi.org/10.1111/jsbm.12090.

Mujiburrahman. (2011). FENOMENOLOGI NIAT. KANZ PHILOSOPHIA, I(2), 215-226.

Muslim Kelana. (2011). Menjadi Usahawan Sehebat Muhammad Bin Abdullah. (Irma Indayu Omar, Ed.) (Ketiga). Selangor, Malaysia: PTS Millennia Sdn Bhd.

Nadia, \& Nawaz. (2017). Intentions to become an entrepreneur: survey from university students of karachi. International Journal of Business, Economics and Law, 13(2).

Nadratun Nafisah, Muhammad Nasri, \& Abdullah. (2017). Faktor Motivasi Dan Kejayaan Firma Usahawan : Amalan Agama Sebagai Penyederhana ( Motivation and Entrepreneur Firm Success : Religious Practice As Moderator ). Journal of Global Business and Social Entrepreneurship, 3(5), 28-35.

Nisson, C., \& Earl, A. (2015). The Theories of Reasoned Action and Planned Behavior: Examining the Reasoned Action Approach to Prediction and Change of Health Behaviors. In The Wiley Encyclopedia of Health Psychology (p. 17).

Province, H., \& Farani, A. Y. (2016). The Role of Entrepreneurial Knowledge and Skills in Developing Digital Entrepreneurial Intentions in Public Universities in The Role of Entrepreneurial Knowledge and Skills in Developing Digital Entrepreneurial Intentions in Public Universities in Hamedan. Irianian Journal of Information Processing and Management, 31(no 3), 785-802.

Ramadani, V., Dana, L. P., Ratten, V., \& Tahiri, S. (2015). The context of Islamic entrepreneurship and business: concept, principles and perspectives. International Journal of Business and 
INTERNATIONAL JOURNAL OF ACADEMIC RESEARCH IN BUSINESS AND SOCIAL SCIENCES Vol. 8, No. 12, Dec, 2018, E-ISSN: 2222-6990 @ 2018 HRMARS

Globalisation, 15(3), 244. https://doi.org/10.1504/IJBG.2015.071906

Ratten, V., Alamanda, D. T., Ramadani, V., Hashani, M., \& Anggadwita, G. (2017). Entrepreneurial intentions from an Islamic perspective: a study of Muslim entrepreneurs in Indonesia. International Journal of Entrepreneurship and Small Business, 31(2), 165. https://doi.org/10.1504/IJESB.2017.10004845

Riaz, Q., Farrukh, M., Shams-Ur-Rehman, \& Ishaque, A. (2016). Religion and entrepreneurial intentions: an empirical investigationl. International Journal of Advanced and Applied Sciences, 3(9), 31-36. Retrieved from http://www.science-gate.com/IJAAS/Articles/2016-3-2/04 2016-32-pp.15-19.pdf

Roy, R., Akhtar, F., \& Das, N. (2017). Entrepreneurial intention among science \& technology students in India: extending the theory of planned behavior. International Entrepreneurship and Management Journal, 13(4), 1013-1041. https://doi.org/10.1007/s11365-017-0434-y

Salmah S, Kalsom AW, Asmaddy H, \& Nordin AR. (2015). The Study of Muslim Intention to Become Muslimpreneurs. Symposium, (Kajian No. 4 Malaysia), 2-12.

Salwa, A. B. U., Shahbudin, A. S., \& Jusoff, K. (2013). Religion and business values for Muslimpreneurs. Middle-East Journal of Scientific Research 13, 13, 61-68. https://doi.org/10.5829/idosi.mejsr.2013.13.1883

Solesvik, M. Z. (2013). Entrepreneurial motivations and intentions: investigating the role of education major. Education + Training, 55(3), 253-271. https://doi.org/10.1108/00400911311309314

Weber, M., Kalberg, S., \& Kebede, A. (1930). The Protestant ethic and the spirit of capitalism. Teaching Sociology (Vol. 30). https://doi.org/10.2307/3211491

Wibowo, B. (2017). Religiosity and Entrepreneurial Intention. Etikonomi, 16(2), 187-206. https://doi.org/10.15408/etk.v16i2.4963

Yazilmiwati Yaacob, I. A. G. A. (2015). Meneliti Hubungan Jihad Perniagaan dengan Pencapaian Usahawan Muslim Berjaya di Malaysiat. Jurnal Pengurusan 44 (2015), 44, 19.

Yusuf, L., Abdul, D., Poespowidjojo, L., \& Muhammed, A. (2017). Akademia Baru Journal of Advanced Research in Business relationship between entrepreneurial knowledge and graduates entrepreneurial intention. Journal of Advanced Research in Business and Management Studies, 7(1 (2017)), 21-31.

Zaidatol, A. L., Bagheri, A., \& Sani, Z. H. A. (2013). Knowledge of Cognition and Entrepreneurial Intentions: Implications for Learning Entrepreneurship in Public and Private Universities. Procedia - Social and Behavioral Sciences, 97, 174-181. https://doi.org/10.1016/j.sbspro.2013.10.219

Zain, M., \& Mubarak, B. (2015). KONSEP KEUSAHAWANAN ISLAM: TERMINOLOGI, KEROHANIAN DAN AL-FALĀH. In International Conference on Islamic Education and Social Entrepreneurship (pp. 1-22). 